\title{
Studies on the origin of human amniotic fluid cells by immunofluorescent staining of keratin filaments
}

\author{
WINSTON W CHEN \\ From the John F Kennedy Institute and Department of Neurology, School of Medicine, Johns Hopkins \\ University, Baltimore, Maryland 21205, USA.
}

SUMMARY Cultivated cells obtained by amniocentesis for antenatal diagnosis were examined for the presence of keratin filaments by immunofluorescent staining techniques. In primary cultures, cells in fibroblast type colonies do not possess keratin filaments whereas cells in epithelial type colonies show positive staining of keratin fibres. The majority of cells in amniotic fluid type colonies also stain positively with antikeratin antibody. After the primary cells have been subcultured, most of them appear fibroblastic yet stain positively with antikeratin antibody. The patterns formed by these stained fibres resemble those seen in primary cultures of amniotic fluid type cells. These results indicate that the amniotic fluid type cells (which predominate in primary cultures) and the majority of cells in subcultures (routinely used for antenatal diagnosis of genetic metabolic disorders) are epithelial in origin.

Cultivated amniotic fluid cells have been widely used for the antenatal diagnosis of genetic metabolic disorders. ${ }^{12}$ These cultures are known to consist of a mixed population of cells, ${ }^{3-5}$ and the basal activities of various enzymes in these cells have been shown to vary according to the cell type and tissue of origin. ${ }^{6-9}$ For diagnostic purposes, therefore, it is important to be able to identify the origin of cells in amniotic fluid cultures. At present, these different cell types are recognised and classified primarily on the basis of morphology into epithelial (E) cells, amniotic fluid (AF) cells, and fibroblast (F) cells. ${ }^{351011}$ Studies of the synthesis of type IV collagen and a glycoprotein component of epithelial basement membrane suggested that at least some of the AF and $F$ cells may also be epithelial in origin. ${ }^{12-14}$

Recent studies have shown that almost all epithelial cells contain abundant keratin filaments. ${ }^{15-18}$ I show here that a great majority of amniotic fluid cells contain keratin filaments and are therefore epithelial in nature.

\section{Materials and methods}

\section{CELL CULTURES}

Amniotic fluid cultures were established according to published procedures. ${ }^{319}$ Briefly, amniotic cells $\left(10^{4}-10^{5}\right)$ were seeded in $35 \mathrm{~mm}$ petri dishes containing $2.5 \mathrm{ml}$ of Eagle's minimum essential medium supplemented with penicillin (100 units/ml), streptoReceived for publication 19 February 1982. mycin $(100 \mu \mathrm{g} / \mathrm{ml})$, glutamine $(34 \mu \mathrm{mol} / \mathrm{l})$, and $25 \%$ fetal calf serum. The cultures were incubated in $5 \%$ $\mathrm{CO}_{2} / 95 \%$ air, humidified atmosphere, and were fed twice a week with the same medium. Colonies of amniotic fluid cells were examined between the 5th and 15th days. Cultured cells were dissociated with $0.2 \%$ trypsin $/ 0.02 \%$ ETDA and seeded into the same growth medium. Subcultured cells, between the 1st and 5th passages, were also examined.

IMMUNOFLUORESCENT STAINING OF KERATIN The preparation and characterisation of an antibody to keratins of human epidermal stratum corneum have been described previously and the antibody to keratins was kindly provided by Dr T T Sun, Johns Hopkins School of Medicine. ${ }^{17}$ Immunofluorescent staining of keratin filaments in cultured amniotic cells was carried out according to the method of Sun and Green. ${ }^{18}$ By using this antikeratin antibody, keratin filaments have been demonstrated in skin keratinocytes in all epithelial cells which line the female genital tract and in various other stratified epithelia, but not in connective tissues or in cultured mesenchymal cells. ${ }^{16} 17$

\section{Results}

IMMUNOFLUORESCENT STAINING OF PRIMARY CULTURES OF AMNIOTIC FLUID CELLS

In 24 amniotic fluid samples examined, the majority of colonies $(>70 \%)$ were identified morphologically 
as AF type cells. The second most frequently observed population contained $\mathrm{E}$ type cells $(20 \%)$. The third cell type, $F$ type, was detected with relatively low frequency $(<10 \%)$. By using the antikeratin antibody, keratin filaments were shown in skin keratinocytes and all epithelial cells of the female genital tract, but not in connective tissues nor in cultured mesenchymal cells. ${ }^{16}{ }^{17}$ In addition, the ability to produce keratin is retained during serial cultivation of human epidermal cells. ${ }^{18}$ When primary cultures of amniotic fluid cells were treated with antikeratin antiserum and examined by indirect immunofluorescence microscopy, ${ }^{18}$ cells in $E$ type colonies showed positive staining which was confined to fibrous structures. In most cases $(>80 \%)$, these keratin filaments were interconnected through intercellular bridges which are presumably anchored in desmosomal attachments. This morphological appearance is similar to that of cultured human epithelial cells. Some E type cells have keratin fibres in radial arrays around the nucleus, while others have arrays of longitudinal fibres (fig 1). Over $90 \%$ of cells in AF type colonies also stained positively with the antikeratin antibody, but here the keratin fibres were exclusively retained in the cytoplasm (fig 2). Thus, the patterns of keratin fibres were different in AF and E type cells. On the other hand, $F$ type colonies did not stain with the antikeratin antiserum suggesting a mesenchymal origin.

IMMUNOFLUORESCENT STAINING OF

SUBCULTURED AMNIOTIC FLUID CELLS

Primary cultures of amniotic fluid cells containing all three cell types were subcultured and grown through five passages. Most of these subcultured cells appeared fibroblastic and grew in swirl patterns or parallel arrays. Despite their fibroblastic appearance, over $90 \%$ of these cells were found to be keratin positive (fig 3 ). The stained fibres resembled the patterns seen in primary cultures of AF type cells.
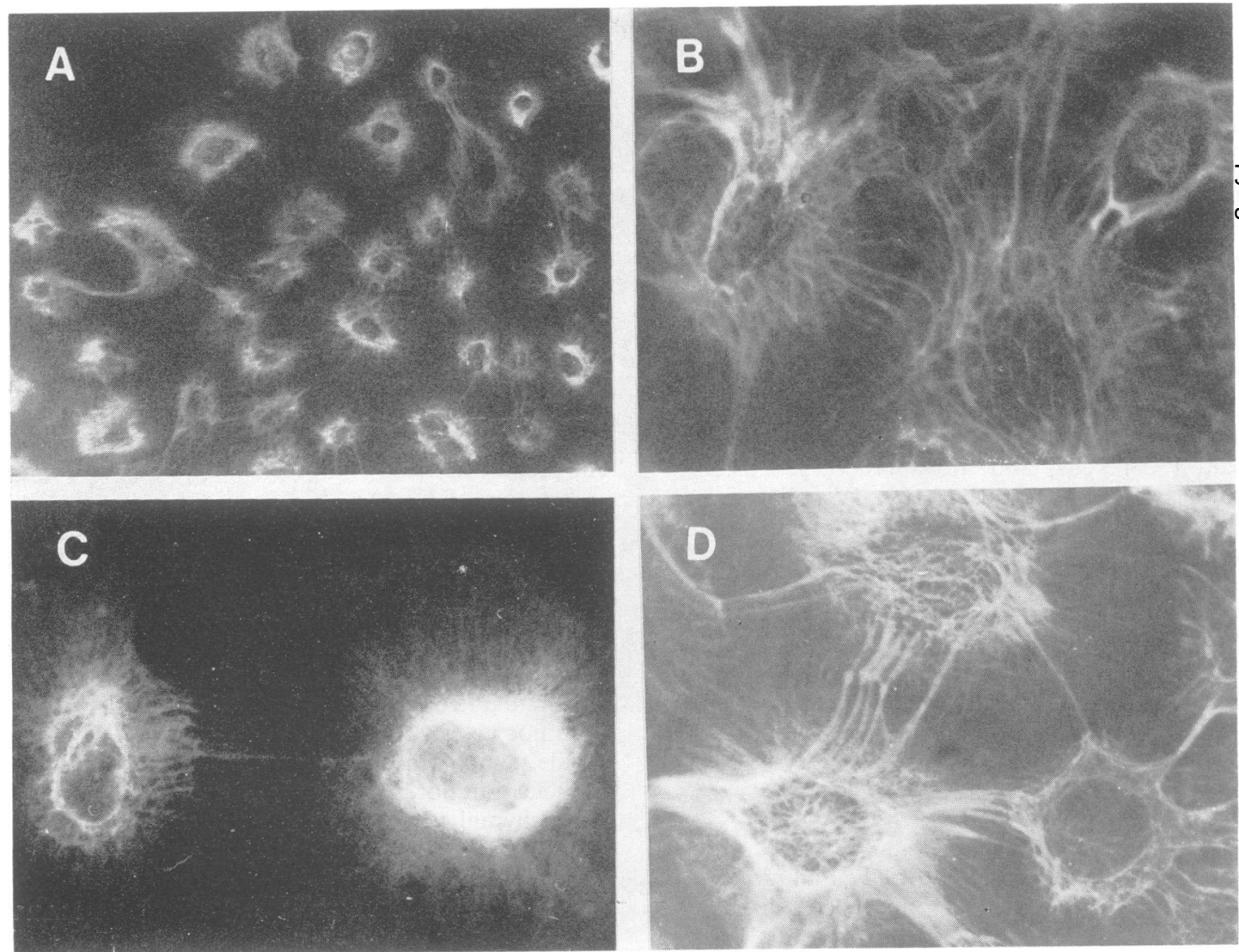

FIG 1 Immunofluorescent staining of keratin filaments in E type cells of primary amniotic fluid cultures. (Original magnifications: $A \times 100 ; B, C, D \times 541$.) 

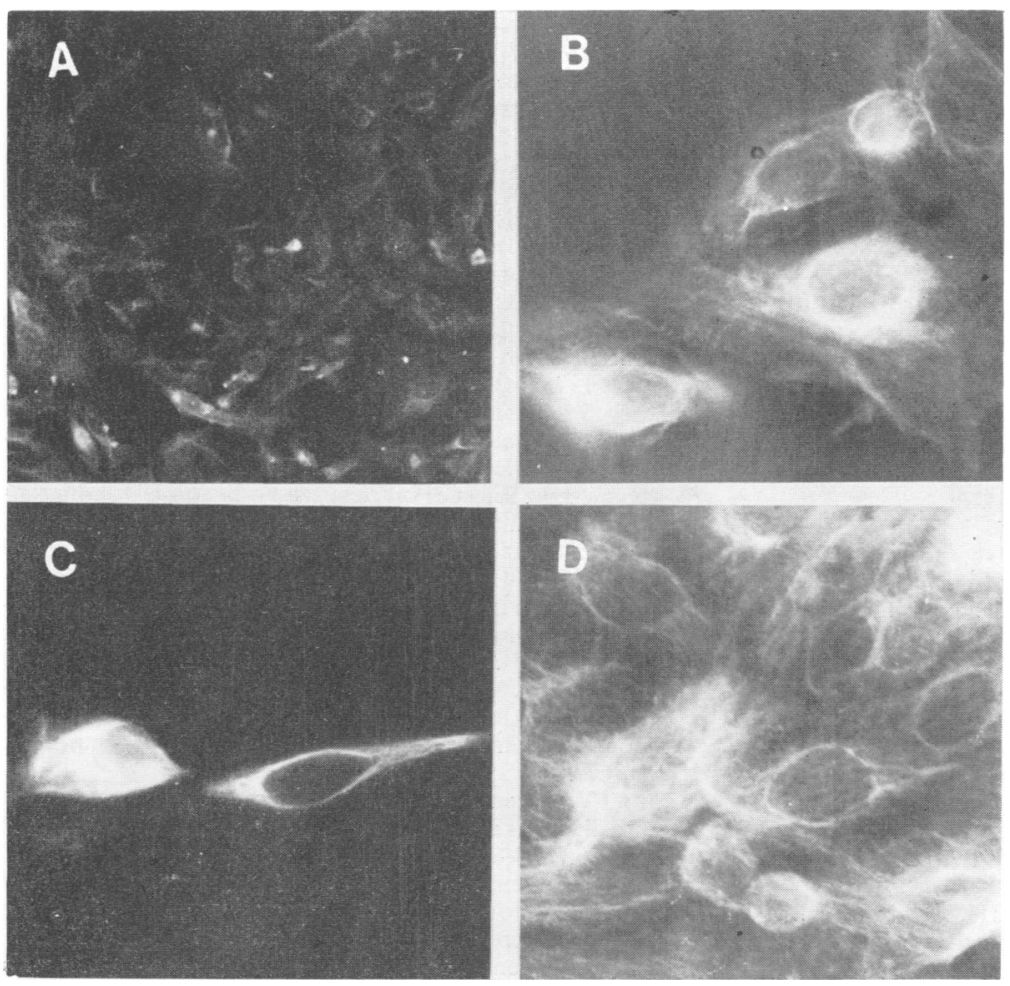

FIG 2 Immunofluorescent micrographs of AF type cells in primary cultures stained for keratin fibres. (Original magnifications: $A \times 100 ; B, C$, $D \times 700$.)
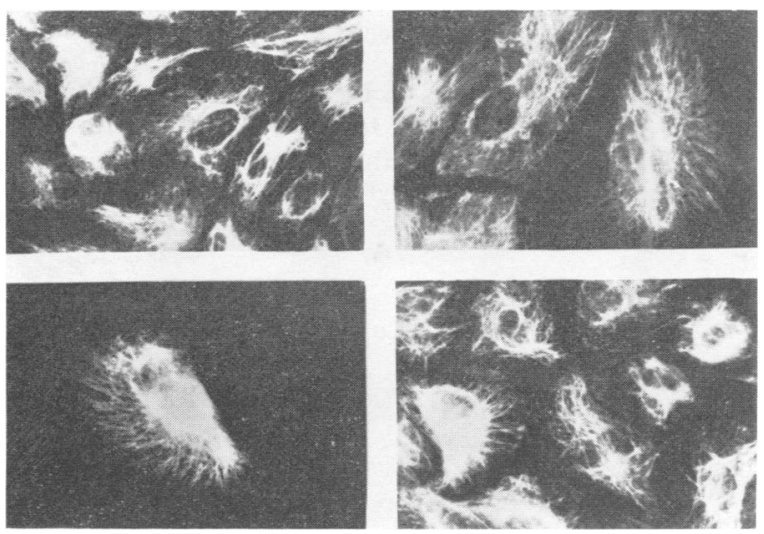

FIG 3 Immunofluorescent staining of subcultures of amniotic fluid cells by antikeratin antibody. (Original magnification $\times 700$.)

\section{Discussion}

Primary cultures of amniotic fluid cells are clearly heterogeneous. However, routine antenatal diagnoses are usually done with subcultures of amniotic fluid cells which are composed of a relatively homogeneous population and are predominantly fibroblast-like cells. ${ }^{12}$ It has been postulated, therefore, that after subculture fibroblastic ( $F$ type) cells have a selective advantage and overgrow other cell types. ${ }^{311} 12$ On the basis of this assumption, enzymatic activities of the AF cultures are routinely compared with cultured skin fibroblasts. ${ }^{6-9}$ I have shown that both $\mathrm{E}$ and AF cell types in primary amniotic fluid cultures are positively stained by antikeratin antibody. In addition, over $90 \%$ of cells in subcultures possess keratin filaments. These primary and subcultured cells are, therefore, epithelial in nature. Based on 
these results it may be concluded that in antenatal diagnosis of metabolic defects a comparison of the enzymatic activity of amniotic fluid cells with that of human diploid skin fibroblast cultures should be approached with caution.

I thank Dr T T Sun for his generous gift of antibody to keratins and his helpful discussion, Dr Jeanette $S$ Flex for her advice and help in cultivating amniotic fluid cells, Mrs A B Moser for her technical assistance, and Dr Pamela Talalay for her expert editorial help. The work was supported in parts by Grants NS 16955, NS 13513, and HD 10981 from the National Institutes of Health.

\section{References}

1 Burton BK, Gerbie AB, Nadler HL. Present status of intrauterine diagnosis of genetic defects. Am J Obstet Gynecol 1974;118:718-46.

2 Milunsky A. The prevention of genetic disease and mental retardation. Philadelphia: Saunders, 1975.

3 Hoehn H, Bryant EM, Karp LE, Martin GM. Cultivated cells from diagnostic amniocentesis in second trimester pregnancies. I Clonal morphology and growth potential. Pediatr Res $1974 ; 8: 746-54$

4 Casadei R, D'Ablaing G, Kaplan B, Schwinn C. A cytological study of amniotic fluid. Acta Cytol 1973;17: 289-98.

5 Priest RE, Karimuthu KM, Priest JH. Origin of cells in human amniotic fluid cultures: ultrastructural features. Lab Invest 1978;39:106-9.

- Gerbie AB, Melancon SB, Ryan C, Nadler HL. Cultivated epithelial-like cells and fibroblasts from amniotic fluid: their relationship to enzymatic and cytologic analysis. Am J Obstet Gynecol 1972;114:314-20.

7 Kaback MM, Leonard CO, Parmaley TH. Intrauterine diagnosis: comparative enzymology of cells cultivated from maternal skin, fetal skin and amniotic fluid cells. Pediatr Res $1971 ; 5: 366-71$.

8 Galjaard H, Sachs ES, Kleijer WJ, Neimeijer MF. Prenatal diagnosis of genetic disease. In: Went LN,
Vermeij-Keers C, Van der Linden AG, eds. Early diagnosis and prevention of genetic diseases. Leiden: Leiden University Press, 1975:82-91.

9 Ven der Veer E, Kleijer WJ, deJosselin deJong JE, Galjaard H. Lysosomal enzyme activities in different $\vec{\omega}$ types of amniotic fluid cells measured by microchemical methods, combined with inference microscope. Hum Genet $1978 ; 40: 285-92$.

10 Sutherland GR, Bauld R, Bain AD. Observations on $\bar{T}$ human amniotic fluid cell strains in serial cultures. $J$ Med $\mathbb{D}$ Genet 1974;11:190-5.

11 Chettur L, Christensen E, Philip J. Stimulation of amniotic fluid cells by fibroblast growth factor. Clin $\overrightarrow{-}$ Genet 1978;14:223-8.

12 Hurych J, Macek M, Beniac F, Rezacova D. Biochemical $\vec{\perp}$ characteristics of collagen produced by long term culti- $\omega$ vated amniotic fluid cells. Hum Genet 1976;31:335-40.

13 Megaw JM, Priest JH, Priest RE, Johnson LD. Differentiation in human amniotic fluid cell cultures. II. Secretion of an epithelial basement membrane glycoprotein. J Med Genet 1977;14:163-7.

14 Priest RE, Priest JH, Moinuddin JF, Keyser AJ. Differentiation in human amniotic fluid cell cultures. I. Collagen $\omega$ production. J Med Genet 1977;14:157-62.

15 Franke WW, Weber K, Osborn M, Schmid E, Frenden- 글 stein C. Antibody to prekeratin: decoration of tonofilament-like arrays in various cells of epithelial character. Exp Cell Res 1978;116:429-45.

16 Sun TT, Green H. Keratin filaments of cultured human epithelial cells in internal organs. Proc Natl Acad Sci USA 1979;76:2813-7.

17 Sun TT, Green H. Keratin filaments of cultured epithelial cells: formation of intermolecular disulfide bonds during terminal differentiation. J Biol Chem 1978;253:2053-60응

18 Sun TT, Green H. Immunofluorescent staining of keratin fibers in cultured cells. Cell 1978;14:469-76.

19 Fenson AH, Benson, PF, Neville BRG, Moser HWD Moser AB, Dulaney JT. Prenatal diagnosis of Farber's disease. Lancet 1979 ;ii:990-2.

Requests for reprints to Dr Winston W Chen, John F Kennedy Institute, Johns Hopkins School of Medicine, 707 N Broadway, Baltimore, Maryland 21205, USA. 